\title{
The Effects of Pseuderanthemum palatiferum, a New Medicinal Plant, on Growth Performances and Diarrhea of Piglets
}

\author{
Huynh Kim DIEU ${ }^{1}$, Chau Ba LOC ${ }^{1}$, Seishi YAMASAKI ${ }^{2 *}$ and \\ Yutaka HIRATA ${ }^{3}$ \\ ${ }^{1}$ Department of Veterinary Medicine, Faculty of Agriculture, Cantho University \\ (3/2 St., Cantho, Vietnam) \\ 2 Animal Production and Grassland Division, Japan International Research Center for Agricultural \\ Sciences (JIRCAS) (Tsukuba, Ibaraki 305-8686, Japan) \\ ${ }^{3}$ Graduate School of Agriculture, Tokyo University of Agriculture and Technology \\ (Fuchu, Tokyo 183-8509, Japan)
}

\begin{abstract}
To evaluate the effect of Pseuderanthemum palatiferum, a new medicinal plant, on piglets' daily weight gain and the effect on piglets with diarrhea, a total of 644 piglets (396 suckling and 248 weaned piglets) were examined using 3 tests for 30 days. Fresh leaves or dried leaf-powder of $P$. palatiferum were fed daily at different dosages or for different durations to the piglets. The dose of $P$. palatiferum to both suckling and weaned piglets could improve the following parameters: growth rate became higher; retarded growth, diarrhea and mortality were decreased; and the number and duration of diarrhea cases were decreased. The dosage during 30 days was more effective than that during 7 days and the leafpowder dosage of $0.2 \mathrm{~g} / \mathrm{kg}$ body weight $(\mathrm{BW}) /$ day was more effective than that of $0.1 \mathrm{~g} / \mathrm{kgBW} /$ day. The effect of the dried leaf-powder was the same as or equivalent to the fresh-leaf. It also kept the piglets in a healthy physiological condition. It is expected that the usage of this plant, especially in the form of leaf-powder, has a high possibility to replace or reduce the amount of antibiotics in pig production systems in future.
\end{abstract}

Discipline: Animal health

Additional key words: Acanthacea, antibiotics, epizootiology, medicinal plant, vegetable functions

\section{Introduction}

Diarrhea is the most serious disease for suckling piglets $^{10}$. Many antibiotics, such as avinamycin, colistin, oxytetracyclin, spectinomycin, and trimethoprim, have been popularly applied for the treatment of the disease ${ }^{9}$. However, drug residues in animal products have been widely recognized as potentially hazardous to human health because of toxicity and allergenicity ${ }^{16}$. In addition, development of drug-resistant bacteria due to overdosage has been a serious problem in the world $^{8}$. Therefore, the efforts to reduce the usage and replace the role of antimicrobial drugs ${ }^{21}$ in animal feed by increasing the usage of probiotics and natural products have been examined.

Pseuderanthemum palatiferum of the Acanthacea family ${ }^{6}$ is known as a new medicinal plant. It was found in the Cuc Phuong forest in Northern Vietnam ${ }^{4}$. NAPRALERT, the medicinal plants' worldwide database of Illinois University, had not reported on the plant in $1995^{12}$. After the discovery, the area of the cultivation as both a medicinal and an ornamental plant has been expanded throughout the country including the Mekong Delta region, the most southern region in the country ${ }^{4,5}$. This plant can allegedly cure many types of human diseases, e.g., wound, trauma, stomachache, colitis, blood pressure, nephritis, and diarrhea ${ }^{4,8,15}$. It has been actually used for treatment and prevention of many types of disease including diarrhea not only for humans but also for animals $^{5}$. On the other hand, studies on the plant have been done during the last several years, and the compounds such as $\beta$-sitosterol, triterpenoid saponin, 1-triacontanol, and salicylic acid have been isolated and purified from the leaf ${ }^{7,21}$. The leaf contains a proteinase called pseuderantin, which possesses very high thermal 
stability and high proteolytic activity ${ }^{14}$. The extracts from the leaf showed antibacterial and antifungal activities $^{8}$. However, no reports have described the effectivity of the plant to animals.

In this study, the effects of application of $P$. palatiferum fresh leaves or dried leaf-powder at different dosage levels or for different durations were tested on suckling and weaned piglets, with the expectation to replace antibiotics by a material from a natural source.

\section{Materials and methods}

\section{Sites and design of the tests}

Before and during the study, P. palatiferum had been cultivated and its fresh leaves were collected at the Experimental Crop Farm of Cantho University. Some of the leaves were dried up to $20 \%$ of fresh weight, and ground into powder. The sequence of studies including three tests, as summarized in Table 1, was conducted at the Experimental Animal Farm of Cantho University. A total of 644 piglets (396 suckling, or newly-born, and 248 weaned piglets) including both male and female were used in the tests. Each of the three tests was conducted for 30 days. The piglets were sorted by their live weight, and those of the same litter were randomly allocated in the three or four different treatment groups of each test. Neither the fresh-leaves nor the leaf-powder of the plant were supplied to the control piglets, but other management conditions were the same among the treatments in each trial as described below. The suckling piglets in the first and second tests (Ex. 1 \& 2) were injected with iron supplement solution at 2 days old besides receiving suckling sows' milk, and were gradually supplemented with commercial creep-feed, Higro 351, produced by Thailand's CP Group Company in Vietnam (the company supplies the chemical composition of feed: dry matter (DM) $86.0 \%$ in feed; crude protein 19.0\% DM; crude fiber 5.0\% DM; calcium 0.7-1.1\% DM; and phosphorus $0.5 \%$ DM). In Ex. 1, P. palatiferum leaves were dosed to the piglets only in the first week (during day 1 to 7, T1-1) or during the whole period (day 1 to 30, T1-2). The creep-feed was fed ad libitum at eight times a day since $7 \mathrm{~d}$, and the amount supplied was gradually increased following the increasing of the piglets' requirements. In Ex. 2, the effects of fresh leaves or leafpowder, and the different dose of the powder for suckling piglets were examined for 30 days. The suckling piglets in Ex. 2 were replaced by weaned piglets in the next test (Ex. 3). The weaned piglets were fed the same commercial feed eight times per day: the amount was gradually increased from around $100 \mathrm{~g} /$ day/piglet at the initial timing to around $650 \mathrm{~g} / \mathrm{day} /$ piglet at the final timing. The other management conditions and the treatments in Ex. 3 were the same as those in Ex. 2.

Table 1. The test designs to determine the effects of Pseuderanthemum palatiferum fresh leaves or leaf-powder on growth performances, diarrhea prevalence and blood physiology of piglets

\begin{tabular}{|c|c|c|c|c|c|c|}
\hline Treatment & $\mathrm{n}$ & $\begin{array}{l}\text { Recipient } \\
\text { (initial BW) }\end{array}$ & P. palatiferum & $\begin{array}{c}\text { Dose } \\
\text { (g/kgBW/day) }\end{array}$ & Route & $\begin{array}{r}\text { Duration of } \\
\text { dosage (day) }\end{array}$ \\
\hline \multicolumn{7}{|l|}{ Ex. 1} \\
\hline $\mathrm{C} 1$ & 52 & \multirow{3}{*}{$\begin{array}{l}\text { Suckling } \\
(1.52-1.53 \mathrm{~kg})\end{array}$} & NT & - & - & - \\
\hline $\mathrm{T} 1-1$ & 52 & & & \multirow{2}{*}{1.0} & \multirow{2}{*}{ Oral } & $1-7$ \\
\hline T1-2 & 52 & & Leaves & & & $1-30$ \\
\hline \multicolumn{7}{|l|}{ Ex. 2} \\
\hline $\mathrm{C} 2$ & 60 & \multirow{4}{*}{$\begin{array}{l}\text { Suckling } \\
(1.74-1.75 \mathrm{~kg})\end{array}$} & NT & - & - & - \\
\hline $\mathrm{T} 2-1$ & 60 & & Leaves & 0.5 & & 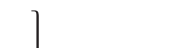 \\
\hline $\mathrm{T} 2-2$ & 60 & & \multirow{2}{*}{ Powder } & 0.1 & Oral & $1-30$ \\
\hline $\mathrm{T} 2-3$ & 60 & & & 0.2 & & \\
\hline \multicolumn{7}{|l|}{ Ex. 3} \\
\hline $\mathrm{C} 3$ & 62 & \multirow{4}{*}{$\begin{array}{l}\text { Weaned } \\
(8.25-8.37 \mathrm{~kg})\end{array}$} & NT & - & - & - \\
\hline T3-1 & 62 & & Leaves & 0.5 & & \\
\hline T3-2 & 62 & & \multirow{2}{*}{ Powder } & 0.1 & In feed & $1-30$ \\
\hline T3-3 & 62 & & & 0.2 & & \\
\hline
\end{tabular}

Growth performances were measured on weight gain and retarded growth rate. Piglets with less than $4 \mathrm{~kg}$ of weight gain for 28 days were considered to have retarded growth. Diarrhea prevalence was measured on daily percentages of diarrhea pigs in the pigs tested, number of diarrhea cases and their duration. The blood physiology was tested on erythrocyte count, packed cell volume, and hemoglobin after finishing each test.

NT: Not treated. 


\section{Parameters}

Number of dead piglets, growth performance, diarrhea prevalence and blood physical condition of the piglets were counted or measured in each treatment of the tests. The growth performance was represented by live weight gain (WG) and number of piglets with retarded growth. The piglets were weighed every seven days, from the 1st to the 28th day, and those with less than $4 \mathrm{~kg} \mathrm{WG}$ during the 28 days were considered to have retarded growth. The diarrhea prevalence was represented by the average daily proportion of diarrhea piglets in the piglets examined, number of diarrhea cases during the whole period of the tests, and duration of diarrhea per case. The piglets' feces were considered as different from the normal ones when they were waterish, poorly digested, and with a greenish or grayish color. This was determined to be diarrhea and the piglet was counted as a diarrhea case. The diarrhea piglets were cured using Chloroxysone produced by Vemedim Co., Ltd. in Vietnam (the company supplies the contents as $200 \mathrm{mg}$ prednisolone, $5 \mathrm{~g}$ oxytetracyclin, and $10 \mathrm{~g}$ chloramphenicol in $100 \mathrm{~mL}$ ) with the dosage of $0.2 \mathrm{~mL} / \mathrm{kg}$ body weight (BW) /day for 2 or 3 days via intramuscular injection. The diarrhea was determined as continued when diarrhea relapsed again within 3 days from the last curing, and it was determined as a new case when diarrhea occurred after more than 4 days from the last curing. Then, the diarrhea duration was calculated. At the end of the tests, $2 \mathrm{~mL}$ of blood was

Table 2. The effect of Pseuderanthemum palatiferum fresh leaves and the duration of the dosage on suckling piglets (Ex. 1)

\begin{tabular}{|c|c|c|c|}
\hline & $\mathrm{C} 1$ & $\mathrm{~T} 1-1$ & $\mathrm{~T} 1-2$ \\
\hline No. of piglets & 52 & 52 & 52 \\
\hline Initial body weight $(\mathrm{kg})^{1,2)}$ & $1.52 \pm 0.05$ & $1.52 \pm 0.05$ & $1.53 \pm 0.05$ \\
\hline No. of dead piglets & 2 & 1 & 0 \\
\hline \multicolumn{4}{|l|}{ Growth performances } \\
\hline \multicolumn{4}{|l|}{ Weight gain $(\mathrm{kg})^{2)}$} \\
\hline $1-7 \mathrm{~d}$ & $0.93 \pm 0.05^{\mathrm{c} *}$ & $1.16 \pm 0.05^{\mathrm{b}}$ & $1.31 \pm 0.05^{\mathrm{a}}$ \\
\hline $8-14 \mathrm{~d}$ & $1.04 \pm 0.08^{\mathrm{b}}$ & $1.18 \pm 0.07^{\mathrm{ab}}$ & $1.29 \pm 0.08^{\mathrm{a}}$ \\
\hline $15-21 \mathrm{~d}$ & $1.17 \pm 0.09$ & $1.33 \pm 0.07$ & $1.40 \pm 0.07$ \\
\hline $22-28 \mathrm{~d}$ & $1.28 \pm 0.16$ & $1.27 \pm 0.10$ & $1.38 \pm 0.07$ \\
\hline Total & $4.42 \pm 0.13^{\mathrm{c}}$ & $4.93 \pm 0.20^{\mathrm{b}}$ & $5.37 \pm 0.15^{\mathrm{a}}$ \\
\hline No. of retarded growth piglets ${ }^{3)}$ & $10^{\mathrm{a}}$ & $3^{b}$ & 1 \\
\hline \multicolumn{4}{|l|}{ Diarrhea prevalence } \\
\hline No. of diarrhea piglets & 52 & 47 & 0 \\
\hline \multicolumn{4}{|c|}{ Average proportion of diarrhea piglets per day (\%) } \\
\hline $1-7 \mathrm{~d}$ & $8.9^{\mathrm{a}}$ & $1.1^{\mathrm{b}}$ & $0.0^{\mathrm{b}}$ \\
\hline $8-14 \mathrm{~d}$ & $29.0^{\mathrm{a}}$ & $15.0^{\mathrm{b}}$ & $0.0^{\mathrm{c}}$ \\
\hline $15-21 \mathrm{~d}$ & $16.4^{\mathrm{a}}$ & $5.7^{\mathrm{b}}$ & $0.0^{\mathrm{b}}$ \\
\hline $22-30 \mathrm{~d}$ & $6.4^{\mathrm{a}}$ & $2.9^{\mathrm{a}}$ & $0.0^{\mathrm{b}}$ \\
\hline No. of diarrhea cases & $95^{\mathrm{a}}$ & $56^{\mathrm{b}}$ & 0 \\
\hline Duration of diarrhea/case (day $)^{4)}$ & $2.18 \pm 0.12^{\mathrm{a}}$ & $1.28 \pm 0.11^{\mathrm{b}}$ & - \\
\hline \multicolumn{4}{|l|}{ Blood physiology 2,5$)$} \\
\hline No. of erythrocyte (million $/ \mathrm{mm}^{3}$ ) & $4.7 \pm 0.0^{\mathrm{b}}$ & $4.9 \pm 0.0^{\mathrm{b}}$ & $5.2 \pm 0.1^{\mathrm{a}}$ \\
\hline Packed cell (\% in total volume) & $31.2 \pm 0.1^{\mathrm{c}}$ & $37.2 \pm 0.4^{\mathrm{b}}$ & $42.1 \pm 0.7^{\mathrm{a}}$ \\
\hline Hemoglobin ( $\%$ in total volume) & $13.9 \pm 0.4^{\mathrm{c}}$ & $16.2 \pm 0.1^{\mathrm{b}}$ & $18.6 \pm 0.3^{\mathrm{a}}$ \\
\hline
\end{tabular}

*: Means within the same row with different superscript letters were significantly different at $\mathrm{p}<0.01$.

1): The newly-born piglets were used for the test.

2): Mean \pm S.E.

3): Piglets with less than $4 \mathrm{~kg}$ of weight gain for 28 days were considered to have retarded growth.

4): Diarrhea prevalence was measured on daily percentages of diarrhea pigs in the pigs tested, number of diarrhea cases and their duration.

5): The 10 piglets were chosen in each treatment test and the blood was sampled.

-: No case. 
sampled from the piglets' ear vein, and the blood physiology was examined on erythrocyte count, packed cell and hemoglobin volumes ${ }^{5}$.

\section{Statistical analysis}

Minitab Statistical Software version 13 was used for the analysis ${ }^{19}$. The chi-square test was done to test hypotheses concerning the frequency distribution of one or more populations. The data of the means was analyzed by ANOVA using the General Linear Model. Sources of variation were treatments in factors. The Tukey Test for paired comparisons was used to separate means when the differences were significant at the $1 \%$ level. The tests were not applied when the frequency or the number of samples were less than three.

\section{Results}

The suckling and weaned piglets preferred both the $P$. palatiferum fresh leaves and leaf-powder, though espe- cially the suckling piglets seemed to prefer the fresh leaves. It was also observed that the piglets were not influenced in their body temperature and activity when dosed with the fresh leaves or leaf-powder.

The piglets' WG during the whole period in Ex. 1 was significantly highest in the piglets dosed with the fresh leaves for 30 days (T1-2), second highest in those fed only in the first week (T1-1), and lowest in the control $(\mathrm{C} 1)$ piglets $(\mathrm{p}<0.01)$ (Table 2$)$. The effect on the WG was clearer in the early growth stage of the piglets: the significant differences $(\mathrm{p}<0.01)$ were found in the $1 \mathrm{st}$ to 2nd weeks; the tendency was found $(0.01<\mathrm{p}<0.05)$ in the 3rd week; and there was no difference in the last week $(\mathrm{p}>0.05)$. The number of growth retarded piglets was significantly lowest in T1-2, next lowest in T1-1, and highest in $\mathrm{C} 1(\mathrm{p}<0.01)$. Administering the leaves to piglets could control diarrhea; there were no cases of diarrhea nor dead piglets in T1-2, though all or most of the piglets experienced diarrhea in $\mathrm{C} 1$ and $\mathrm{T} 1-1$, the average prevalence of diarrhea was decreased in the $1 \mathrm{st}$

Table 3. The effect of Pseuderanthemum palatiferum fresh leaves or leaf-powder on suckling piglets (Ex. 2)

\begin{tabular}{|c|c|c|c|c|}
\hline Parameter & $\mathrm{C} 2$ & $\mathrm{~T} 2-1$ & $\mathrm{~T} 2-2$ & $\mathrm{~T} 2-3$ \\
\hline No. of piglets & 60 & 60 & 60 & 60 \\
\hline Initial body weight $(\mathrm{kg})^{1,2)}$ & $1.75 \pm 0.06$ & $1.76 \pm 0.06$ & $1.77 \pm 0.06$ & $1.75 \pm 0.06$ \\
\hline No. of dead piglets & $12^{\mathrm{a} *}$ & $4^{b}$ & $3^{\mathrm{b}}$ & 0 \\
\hline \multicolumn{5}{|l|}{ Growth performances } \\
\hline \multicolumn{5}{|l|}{ Weight gain $(\mathrm{kg})^{2)}$} \\
\hline $1-7 \mathrm{~d}$ & $1.00 \pm 0.07^{\mathrm{c}}$ & $1.36 \pm 0.07^{\mathrm{b}}$ & $1.36 \pm 0.07^{\mathrm{b}}$ & $1.74 \pm 0.08^{\mathrm{a}}$ \\
\hline $8-14 \mathrm{~d}$ & $0.89 \pm 0.08^{\mathrm{c}}$ & $1.25 \pm 0.1^{\mathrm{b}}$ & $1.25 \pm 0.1^{\mathrm{b}}$ & $1.61 \pm 0.09^{\mathrm{a}}$ \\
\hline $15-21 \mathrm{~d}$ & $1.01 \pm 0.07^{\mathrm{b}}$ & $1.21 \pm 0.08^{\mathrm{ab}}$ & $1.20 \pm 0.08^{\mathrm{ab}}$ & $1.38 \pm 0.08^{\mathrm{a}}$ \\
\hline $22-28 \mathrm{~d}$ & $1.21 \pm 0.08^{\mathrm{b}}$ & $1.35 \pm 0.09^{\mathrm{ab}}$ & $1.40 \pm 0.09^{\mathrm{ab}}$ & $1.51 \pm 0.09^{\mathrm{a}}$ \\
\hline Total & $4.12 \pm 0.21^{\mathrm{c}}$ & $5.17 \pm 0.21^{\mathrm{b}}$ & $5.20 \pm 0.21^{\mathrm{b}}$ & $6.24 \pm 0.17^{\mathrm{a}}$ \\
\hline No. of retarded growth piglets ${ }^{3)}$ & $11^{\mathrm{a}}$ & $4^{\mathrm{b}}$ & $3^{\mathrm{b}}$ & 0 \\
\hline \multicolumn{5}{|l|}{ Diarrhea prevalence } \\
\hline No. of diarrhea piglets & $50^{\mathrm{a}}$ & $19^{\mathrm{b}}$ & $19^{\mathrm{b}}$ & 2 \\
\hline \multicolumn{5}{|c|}{ Average proportion of diarrhea piglets per day (\%) } \\
\hline $1-7 \mathrm{~d}$ & $31.1^{\mathrm{a}}$ & $6.5^{\mathrm{b}}$ & $6.5^{\mathrm{b}}$ & $0.0^{\mathrm{b}}$ \\
\hline $8-14 \mathrm{~d}$ & $43.2^{\mathrm{a}}$ & $9.1^{\mathrm{b}}$ & $9.1^{\mathrm{b}}$ & $0.2^{\mathrm{c}}$ \\
\hline $15-21 \mathrm{~d}$ & $30.3^{\mathrm{a}}$ & $5.0^{\mathrm{b}}$ & $5.0^{\mathrm{b}}$ & $0.0^{\mathrm{b}}$ \\
\hline $22-30 \mathrm{~d}$ & $23.4^{\mathrm{a}}$ & $3.6^{\mathrm{b}}$ & $3.6^{\mathrm{b}}$ & $0.0^{\mathrm{b}}$ \\
\hline No. of diarrhea cases & $202^{\mathrm{a}}$ & $66^{\mathrm{b}}$ & $62^{\mathrm{b}}$ & 2 \\
\hline Duration of diarrhea/case (day $)^{4)}$ & $2.21 \pm 0.10^{\mathrm{a}}$ & $1.06 \pm 0.17^{\mathrm{b}}$ & $1.02 \pm 0.16^{\mathrm{b}}$ & $0.04 \pm 0.04^{\mathrm{c}}$ \\
\hline \multicolumn{5}{|l|}{ Blood physiology 2,5$)$} \\
\hline No. of erythrocyte (million $/ \mathrm{mm}^{3}$ ) & $4.5 \pm 0.1^{\mathrm{c}}$ & $5.1 \pm 0.1^{\mathrm{b}}$ & $5.1 \pm 0.1^{\mathrm{b}}$ & $6.1 \pm 0.2^{\mathrm{a}}$ \\
\hline Packed cell volume $(\%)$ & $29.0 \pm 0.6^{c}$ & $32.7 \pm 0.3^{\mathrm{b}}$ & $32.5 \pm 0.3^{\mathrm{b}}$ & $42.4 \pm 0.9^{\mathrm{a}}$ \\
\hline Hemoglobin volume (\%) & $11.2 \pm 0.1^{\mathrm{c}}$ & $12.0 \pm 0.1^{\mathrm{b}}$ & $12.0 \pm 0.1^{\mathrm{b}}$ & $13.0 \pm 0.2^{\mathrm{a}}$ \\
\hline
\end{tabular}

*: Means within the same row with different superscript letters were significantly different at $\mathrm{p}<0.01$.

1-5): See Table 2. 
to 3rd weeks, and the recovered rate and the diarrhea duration was improved in T1-1 when compared to $\mathrm{C} 1$ $(\mathrm{p}<0.01)$. The T1-2 piglets had improved blood physiological conditions, though the T1-1 piglets also kept a healthy condition $(\mathrm{p}<0.01)$.

The WG during the first two weeks and during the whole period in Ex. 2 was highest in the T2-3, second highest in T2-1 or T2-2, and lowest in the control (C2) suckling piglets $(\mathrm{p}<0.01)$ (Table 3$)$. The WG in the later two weeks also had nearly the same tendencies. There was no retarded growth of piglets in T2-3. The number of retarded growth piglets was significantly lower in T2-2 and $\mathrm{T} 2-1$ than that in $\mathrm{C} 1(\mathrm{p}<0.01-0.05)$. The results related with diarrhea prevalence and blood physiology were also most improved in $\mathrm{T} 2-3$ but $\mathrm{T} 2-2$ was intermediate between $\mathrm{T} 2-3$ and $\mathrm{C} 2(\mathrm{p}<0.01-0.05)$. The tendencies in the results related with the growth performances, diarrhea prevalence, and blood physiological condition in Ex. 3 were the same as those in Ex. 2; the application of the powder at $0.2 \mathrm{~g} / \mathrm{kgBW} /$ day was the most effective, though application of fresh leaves at $0.5 \mathrm{~g} / \mathrm{day} / \mathrm{kgBW}$ or powder at $0.1 \mathrm{~g} / \mathrm{kgBW} /$ day were also effective $(\mathrm{p}<0.01-0.05)$ (Table 4$)$.

\section{Discussion}

No side effects of the plant on the piglets were seen in this experiment. The minimum inhibitory concentrations of the plant were calculated from the report of Khanh et al. (1998) as $0.75-1.5 \mathrm{~g}$ fresh leaves or $0.15-0.3 \mathrm{~g}$ leafpowder $/ \mathrm{kgBW}$ for treatment ${ }^{8}$. Though the plant was dosed for the prevention of diseases, the concentration used in the tests was less than the minimum inhibitory concentrations which could avoid the side effects.

The application of $P$. palatiferum fresh leaves or leaf-powder could improve the parameters measured. The results might be explained from the contents of the plant as follows. First, $P$. palatiferum leaf contains a higher proportion of crude protein $(30.8 \% \mathrm{DM})^{15} \mathrm{com}-$ pared with elephant grass $(18.6 \% \mathrm{DM})$ and kudzu $(18.4 \%$

Table 4. Effect of Pseuderanthemum palatiferum fresh leaves or leaf-powder on weaned piglets (Ex. 3)

\begin{tabular}{|c|c|c|c|c|}
\hline Parameter & $\mathrm{C} 3$ & T3-1 & T3-2 & T3-3 \\
\hline No. of piglets & 62 & 62 & 62 & 62 \\
\hline Initial body weight $(\mathrm{kg})^{1)}$ & $8.42 \pm 0.36$ & $8.20 \pm 0.23$ & $8.32 \pm 0.34$ & $8.42 \pm 0.35$ \\
\hline No. of dead piglets & $14^{\mathrm{a} *}$ & $4^{\mathrm{b}}$ & $3^{\mathrm{b}}$ & 2 \\
\hline \multicolumn{5}{|l|}{ Growth performances } \\
\hline \multicolumn{5}{|l|}{ Weight gain $(\mathrm{kg})^{1,2)}$} \\
\hline $1-7 \mathrm{~d}$ & $0.48 \pm 0.05$ & $0.42 \pm 0.03$ & $0.36 \pm 0.01$ & $0.47 \pm 0.06$ \\
\hline $8-14 \mathrm{~d}$ & $1.62 \pm 0.15^{\mathrm{b}}$ & $1.87 \pm 0.0^{\mathrm{b}}$ & $1.91 \pm 0.10^{\mathrm{ab}}$ & $2.17 \pm 0.14^{\mathrm{a}}$ \\
\hline $15-21 \mathrm{~d}$ & $2.18 \pm 0.15^{\mathrm{b}}$ & $2.37 \pm 0.13^{\mathrm{b}}$ & $2.38 \pm 0.15^{\mathrm{ab}}$ & $2.57 \pm 0.09^{\mathrm{a}}$ \\
\hline $22-28 \mathrm{~d}$ & $2.36 \pm 0.10^{\mathrm{c}}$ & $2.64 \pm 0.08^{\mathrm{b}}$ & $2.58 \pm 0.07^{\mathrm{b}}$ & $2.85 \pm 0.06^{\mathrm{a}}$ \\
\hline Total & $6.64 \pm 0.22^{\mathrm{c}}$ & $7.30 \pm 0.17^{\mathrm{b}}$ & $7.22 \pm 0.15^{\mathrm{b}}$ & $8.05 \pm 0.21^{\mathrm{a}}$ \\
\hline No. of retarded growth piglets ${ }^{3)}$ & 7 & 2 & 3 & 1 \\
\hline \multicolumn{5}{|l|}{ Diarrhea prevalence } \\
\hline No. of diarrhea piglets & $61^{\mathrm{a}}$ & $44^{\mathrm{b}}$ & $48^{\mathrm{b}}$ & $21^{\mathrm{c}}$ \\
\hline \multicolumn{5}{|c|}{ Average proportion of diarrhea piglets per day (\%) } \\
\hline $1-7 \mathrm{~d}$ & $15.2^{\mathrm{a}}$ & $9.3^{\mathrm{b}}$ & $9.5^{\mathrm{b}}$ & $5.2^{\mathrm{c}}$ \\
\hline $8-14 \mathrm{~d}$ & $14.4^{\mathrm{a}}$ & $6.4^{\mathrm{b}}$ & $7.2^{\mathrm{b}}$ & $1.2^{\mathrm{c}}$ \\
\hline $15-21 \mathrm{~d}$ & $9.8^{\mathrm{a}}$ & $5.0^{\mathrm{b}}$ & $4.7^{\mathrm{b}}$ & $0.4^{\mathrm{c}}$ \\
\hline $22-30 \mathrm{~d}$ & $7.2^{\mathrm{a}}$ & $3.4^{\mathrm{b}}$ & $3.3^{\mathrm{b}}$ & $0.4^{\mathrm{c}}$ \\
\hline No. of diarrhea cases & $119^{\mathrm{a}}$ & $73^{\mathrm{b}}$ & $75^{\mathrm{b}}$ & $27^{\mathrm{c}}$ \\
\hline Duration of diarrhea/case (day $)^{4)}$ & $1.88 \pm 0.05^{\mathrm{a}}$ & $1.52 \pm 0.04^{\mathrm{b}}$ & $1.47 \pm 0.09^{\mathrm{b}}$ & $1.21 \pm 0.08^{\mathrm{b}}$ \\
\hline \multicolumn{5}{|l|}{ Blood physiology 2,5$)$} \\
\hline No. of erythrocyte (million $/ \mathrm{mm}^{3}$ ) & $5.7 \pm 0.3^{\mathrm{b}}$ & $6.4 \pm 0.2^{\mathrm{ab}}$ & $6.3 \pm 0.2^{\mathrm{ab}}$ & $7.0 \pm 0.2^{\mathrm{a}}$ \\
\hline Packed cell volume $(\%)$ & $32.6 \pm 0.5^{\mathrm{b}}$ & $35.0 \pm 0.4^{\mathrm{b}}$ & $34.9 \pm 0.7^{\mathrm{b}}$ & $38.2 \pm 1.0^{\mathrm{a}}$ \\
\hline Hemoglobin volume (\%) & $10.4 \pm 0.3^{\mathrm{b}}$ & $11.3 \pm 0.2^{\mathrm{b}}$ & $11.3 \pm 0.2^{\mathrm{b}}$ & $12.6 \pm 0.2^{\mathrm{a}}$ \\
\hline
\end{tabular}

*: Means within the same row with different superscript letters were significantly different at $\mathrm{p}<0.01$.

1): The piglets just after the finish of their weaning were used for the test.

2-5): See Table 2. 
$\mathrm{DM})^{13}$, though the effect of the dose would be very small because of its small proportion in the diets. Second, the leaf has a high content of some mineral elements such as $\mathrm{Ca}(6.5 \% \mathrm{DM}), \mathrm{K}(4.4 \% \mathrm{DM}), \mathrm{Mg}$ (6.3\% DM), and $\mathrm{Fe}$ $(0.3 \% \mathrm{DM})^{1,15,17}$. The Fe quantity is, especially in the minerals, four times higher than soybean and three times higher than pig liver ${ }^{1}$. Fe in the plant would contribute to improve the blood physiological conditions, as $\mathrm{Fe}$ is necessary for piglets to process erythrocyte, especially hemoglobin, that functionate as a carrier for oxygen and carbon dioxide so known as a respiratory pigment and elucidates the condition of the erythron ${ }^{3}$. Third, the leaf contains a thermostable proteinase named pseuderantin ( $0.4 \%$ in crude protein basis) which has a strong activity on casein digestion and therefore the digestion of milk would be helped by the supplementation of the leaf ${ }^{14}$. Fourth, other chemical substances determined in the plant, such as $\beta$-sitosterol $(0.1 \% \mathrm{DM})$, triterpenoid saponin (purified traceably), 1-triacontanol ( $0.8 \mathrm{~g} / 95 \mathrm{~g}$ extract in hexane), and some of the antibacterial agents might have an influence on the growth and the immunity of the piglets $2,7,8,11,20$. However, only the factors that are supposed to affect the parameters measured are pointed out in the above, and it is not known what factor is the most important one or what is the mechanism of the $P$. palatiferum fresh leaves and leaf-powder in the piglets' body. In addition, the optimum dose level should be determined.

The effect of the dried leaf-powder was the same as or equivalent to the fresh-leaf. As the powder form is more convenient for storage and dosage, the application of the leaf-powder is recommended. The leaf-powder was more effective at the dosage of $0.2 \mathrm{~g} / \mathrm{kgBW} /$ day than that of $0.1 \mathrm{~g} / \mathrm{kgBW} /$ day. The plant grows very fast and is easy to be cultivated not only in northern Vietnam but also in the Mekong Delta, though the number of households which cultivated the plant was small ${ }^{5}$. Therefore, the spread of its cultivation and the application to animals is expected to replace and/or reduce the amount of antibiotics used.

\section{Conclusion}

Application of the $P$. palatiferum leaf-powder at the amount of $0.2 \mathrm{~g} / \mathrm{kgBW} /$ day for 30 days to both suckling and weaned piglets could be recommended to improve the weight gain, and to prevent diarrhea. It is expected that the usage of this plant has a high possibility to replace or reduce the amount of antibiotics in pig production systems in future; in addition further study on the mechanism of $P$. palatiferum in the body of piglets is needed.

\section{References}

1. Bac, V. H. \& Oanh, L. T. L. (2003) Amino acid and mineral contents in the leaf of Pseuderanthemum palatiferum. J. Mater. Med., 8(1), 11-15 [In Vietnamese with English summary].

2. Chien, T. T. (2000) Pork industry handbook. Agriculture Publisher, Hanoi, Vietnam, 267-271 [In Vietnamese].

3. Coles, E. H. (1967) Veterinary clinical pathology. W. B. Saunders Company, USA, 75-84.

4. Cuong, N. D. \& Quynh, N. H. (1999) Pseuderanthemum palatiferum (Nees) Radlk. Pharmaceutical encyclopedia. Encyclopedia Publisher, Hanoi, 714 [In Vietnamese].

5. Dieu, H. K. et al. (2005) The ethnobotanical and botanical study on Pseuderanthemum palatiferum as a new medicinal plant in the Mekong Delta of Vietnam. JARQ, 39(3), 191-196.

6. Ho, P. H. (2000) Vietnamese vegetation. Young Publishing House, 3, 69 [In Vietnamese].

7. Hung, N. V., Tuan, L. A. \& Chien, N. Q. (2003) Keeping on the studies on chemical composition of Pseuderanthemum palatiferum. In Proceedings of the 4th national scientific symposium, October 2003. Vietnam. 286 [In Vietnamese].

8. Khanh, T. C. et al. (1998) Contribution to the studies on botany, chemical composition and biological activities of Pseuderanthemum palatiferum (Nees) Radlk. J. Mater. Med., 3(2), 37-41 [In Vietnamese].

9. Kyriakis, S. C. et al. (1994) The effect of avilamycin and tylosin on the adhesive E. coli and on enteric colibacillosis of piglets pre- and post-weaning. In The 13th international pig veterinary society congress. Bangkok, Thailand. 217.

10. Leman, A. D. et al. (1996) Diseases of swine. 7th ed., Iowa State University Press, Iowa, U.S.A., 487-511.

11. Michael, L. M. D. (2004) Beta-sitosterol. An insider's guide to natural medicine. Available online at http:// www.drlam.com/opinion/beta_sitosterol.cfm (Verified 2 July 2004).

12. Napralert (Natural Products ALERT) database. Pseuderanthemum genus. Available online at http://www.uic.edu/ pharmacy/depts/pmch/napralert (Verified 7 June 1995).

13. National Institute of Animal Husbandry (1995) Composition and nutritive value of animal feeds in Vietnam. Agricultural Publishing House, Hanoi [In Vietnamese].

14. Oanh, L. T. et al. (1998) Purification and investigation of a proteolytic enzyme from leaves of medicinal plant Pseuderanthemum palatiferum (Nees) Radlk. Annual report. Institute of Biotechnology, National Center for Natural Science and Technology, 114-123 [In Vietnamese with English summary].

15. Oanh, L. T. et al. (1999) Investigation of some biochemical characters of proteolytic activity of Pseuderanthemum palatiferum. J. Mater. Med., 4(1), 13-17 [In Vietnamese].

16. Pearson, A. M. \& Dutson, T. R. (1990) Meat and health. Advances in meat research. Vol. VI. Elsevier Applied Science, New York, 135-155.

17. Pham, L. D. (1982) Amino acid and enzyme in animal production. Science and Technology Publisher, Hanoi, 
19-24 [In Vietnamese].

18. Prescott, J. F. \& Baggot, J. D. (1993) Antimicrobial therapy in veterinary medicine. 2nd ed., Iowa State University Press, U. S. A., 21-33 \& 562-568.

19. Ryan, B. F., Joiner, B. L. \& Ryan, T. A. Jr. (2000) Minitab statistical software release 13. Duxbury Press, Boston.

20. Thu, N. T. M. (1999) Contribution to the studies on bot- any, chemical composition and biological activities of Pseuderanthemum palatiferum (Nees) Radlk. University of Pharmacology, Hanoi. MSc thesis [In Vietnamese].

21. Tuong, N. P. \& Uyen, T. D. (2000) Application of veterinary medicines and pharmaceuticals II. Agriculture Press, Hanoi, 113-115 [In Vietnamese]. 